$9-28-2020$

\title{
Coastal Marsh Degradation Into Ponds Induces Irreversible Elevation Loss Relative to Sea Level in a Microtidal System
}

Lennert Schepers

Patrick Brennand

Matthew L. Kirwan

Virginia Institute of Marine Science

Glenn Guntenspergen

Stijn Temmerman

Follow this and additional works at: https://scholarworks.wm.edu/vimsarticles

Part of the Sedimentology Commons

\section{Recommended Citation}

Schepers, Lennert; Brennand, Patrick; Kirwan, Matthew L.; Guntenspergen, Glenn; and Temmerman, Stijn, Coastal Marsh Degradation Into Ponds Induces Irreversible Elevation Loss Relative to Sea Level in a Microtidal System (2020). Geophysical Research Letters, 47(18), e2020GL089121. doi: 10.1029/2020GL089121

This Article is brought to you for free and open access by the Virginia Institute of Marine Science at W\&M ScholarWorks. It has been accepted for inclusion in VIMS Articles by an authorized administrator of W\&M ScholarWorks. For more information, please contact scholarworks@wm.edu. 


\section{Geophysical Research Letters}

\author{
RESEARCH LETTER \\ 10.1029/2020GL089121 \\ Key Points: \\ - Interior marsh ponds deepen with \\ wider channels connecting the \\ ponds, indicating sediment export \\ through these channels \\ - Vegetated marshes and ponds \\ occupy alternative stable elevation \\ states, which impairs marsh \\ recovery once converted to open \\ ponds
}

Supporting Information:

- Supporting Information S1

Correspondence to:

L. Schepers,

lennert.schepers@vliz.be

Citation:

Schepers, L., Brennand, P., Kirwan, M. L., Guntenspergen, G. R., \& Temmerman, S. (2020). Coastal marsh degradation into ponds induces irreversible elevation loss relative to sea level in a microtidal system. Geophysical Research Letters, 47, e2020GL089121. https://doi.org/ 10.1029/2020GL089121

Received 9 JUN 2020

Accepted 31 AUG 2020

Accepted article online 9 SEP 2020

C2020. American Geophysical Union. All Rights Reserved.
Coastal Marsh Degradation Into Ponds Induces Irreversible Elevation Loss Relative to Sea Level in a Microtidal System

\author{
Lennert Schepers $^{1,2}$ iD, Patrick Brennand ${ }^{3}$, Matthew L. Kirwan ${ }^{4}$ iD, \\ Glenn R. Guntenspergen ${ }^{3}$, and Stijn Temmerman ${ }^{1}$ \\ ${ }^{1}$ Ecosystem Management Research Group, University of Antwerp, Antwerp, Belgium, ${ }^{2}$ Flanders Marine Institute (VLIZ), \\ InnovOcean Site, Ostend, Belgium, ${ }^{3}$ Patuxent Wildlife Research Center, U.S. Geological Survey, Laurel, MD, USA, \\ ${ }^{4}$ Department of Physical Sciences, Virginia Institute of Marine Science, College of William and Mary, Gloucester Point, \\ VA, USA
}

\begin{abstract}
Coastal marshes and their valuable ecosystem services are feared to be lost by sea level rise, yet the mechanisms of marsh degradation into ponds and potential recovery are poorly understood. We quantified and analyzed elevations of marsh surfaces and pond bottoms along a marsh loss gradient (Blackwater River, Maryland, USA). Our analyses show that ponds deepen with increasing tidal channel width connecting the ponds to the river, indicating a new feedback mechanism where channels lead to enhanced tidal export of pond bottom material. Pond elevations also decrease with increasing pond size, consistent with previous work identifying a positive feedback between wind wave erosion and pond size. These two positive feedbacks, combined with bimodal elevation distributions and sharp topographic boundaries between interior ponds and the marsh platform, indicate alternative elevation states and imply that marsh loss by pond formation is nearly irreversible once pond deepening exceeds a critical level.
\end{abstract}

Plain Language Summary Coastal marshes are highly valued ecosystems, but in some areas with increased sea level rise these vegetated marshes disappear and convert into large ponds. Currently, we do not fully understand how these ponds are formed and why marsh vegetation is not recovering in these areas. In this study we measured the soil elevation of marshes and ponds in an area where large marsh surfaces have converted to ponds (Blackwater River, Maryland, USA). We found that ponds are generally deeper when the connection of the ponds with the tidal channels is wider. This indicates that pond sediments can be exported through these channels, and the wider the channel, the easier sediment is exported, leading to deeper ponds. Larger ponds are also deeper because larger waves can develop there, resulting in more wave erosion. These two processes both lead to deeper ponds. Furthermore, we found that there is a sharp elevation drop from the marsh platform into ponds, and that intermediate elevations rarely occur. These all suggest that ponds, once they are formed, are very difficult to recover into marsh vegetation.

\section{Introduction}

Marsh conversion to interior ponds is considered an important mechanism of coastal marsh loss, particularly where sediment supply and tidal range are very low (e.g., Kearney et al., 1988; Mariotti, 2016; Mariotti \& Fagherazzi, 2013; Morton et al., 2003; Penland et al., 2000), with large implications for the loss of highly valued ecosystem services, such as protection against storm impacts (Möller et al., 2014; Stark et al., 2015; Temmerman et al., 2013), nursery habitat for fisheries (Barbier et al., 2011), and storage of soil carbon (Duarte et al., 2013; McLeod et al., 2011).

We hypothesize that marshes and interior open water ponds can be considered alternative stable geomorphic states within the larger coastal marsh ecosystem. This would have the important implication that marsh conversion to ponds is very hard to reverse, as each state is typically sustained by positive feedback mechanisms that provide long-term stability (Moffett \& Gorelick, 2016; Scheffer et al., 2001). Marshes have been identified as one stable state of intertidal landforms (Fagherazzi et al., 2006; Marani et al., 2010; van Belzen et al., 2017; Wang \& Temmerman, 2013), as they maintain their elevation relative to rising sea level by feedbacks between tidal inundation and accretion of mineral and organic sediments (Kirwan \& 
Megonigal, 2013; Morris et al., 2002; Temmerman et al., 2004). However, it is unknown if marsh ponds are an alternative, low-elevated state. Previous work suggests that positive feedbacks such as collapse and disintegration of underlying soil organic matter after initial vegetation die-off may reinforce the pond state (Day et al., 2011; Delaune \& Pezeshki, 1994; van Huissteden \& van de Plassche, 1998). Furthermore, modeling and aerial image analysis suggest that ponds expand by wind wave erosion after they reach a critical size (>200 m, Mariotti, 2016; Ortiz et al., 2017). However, expanding ponds may recover when they intersect a tidal channel and when drainage and sediment infilling promotes the recovery of marsh vegetation (Millette et al., 2010; Perillo et al., 1996; Redfield, 1972; Wilson et al., 2009, 2010). Hence, we do not currently understand whether interior marsh ponds represent an alternative stable state, and we lack field data on elevation changes after marsh conversion to ponds, necessary to understand whether marsh collapse is irreversible.

Here, we report the results of a field study along the Blackwater River marshes (Maryland, USA) where relative sea level rise rates are 3-4 times the global average (Sallenger et al., 2012) and widespread marsh loss is well documented by aerial pictures for about the past century (Schepers et al., 2017). We made measurements of marsh and pond bottom elevation along transects in marshes at five stages of marsh degradation, from intact to completely degraded marshes (Schepers et al., 2017). We identify sediment export through connecting channels as a new mechanism for pond deepening and show that topographic characteristics of marshes and ponds are consistent with alternative states, suggesting that reversal of pond expansion is unlikely in these rapidly deteriorating marshes.

\section{Methods}

\subsection{Study Area}

The Blackwater marshes $\left(38^{\circ} 24^{\prime} \mathrm{N}, 76^{\circ} 40^{\prime} \mathrm{W}\right.$, supporting information Figure $\left.\mathrm{S} 1\right)$ are organogenic, microtidal marshes that discharge into Fishing Bay, an embayment of the Chesapeake Bay. Previous research showed that the marshes are being converted to open water ponds at least since the 1930s (Schepers et al., 2017). There is a spatial gradient in marsh loss from intact marshes close to Fishing Bay, to increasing pond surface area with increasing distance upstream the Blackwater River up to Lake Blackwater, a vast open water area that consisted of marshes back in the 1930s (Figures 1 and S2). Marsh loss has been attributed to insufficient surface accretion (on average 1.7-3.6 $\mathrm{mm} \mathrm{yr}^{-1}$; Stevenson et al., 1985) compared to relative sea level rise (currently $3.83 \mathrm{~mm} \mathrm{yr}^{-1}$ nearby in Cambridge, MD, NOAA station 8571892, http://tidesandcurrents.noaa. gov/sltrends, 2 May 2020), disturbance by invasive Nutria (Myocastor coypus) (Kendrot, 2011; Stevenson et al., 1985), and lateral erosion of the ponds (Ganju et al., 2013; Stevenson et al., 1985).

\subsection{Soil Elevation Measurements}

We selected five field sites along the marsh loss gradient (Schepers et al., 2020; Figure S1). At each field site, three parallel marsh transects of 1,000 m length (each $250 \mathrm{~m}$ apart) that straddle the Blackwater River were generated, and points were selected with a $10 \mathrm{~m}$ interval along the transects by using a geographic information system (GIS) (ArcGIS 10.3, ESRI). We located each point in the field in the summer of 2014 and recorded the elevation relative to the North American Vertical Datum of 1988 (NAVD88) with a high-precision GPS (Trimble R8 RTK-GPS, vertical error $<2 \mathrm{~cm}$, at Site 5 vertical error $<4.5 \mathrm{~cm}$ ). Points located in tidal channels were not included in the analyses. At the degraded Site 5, points located in the 1938 channel were also excluded. For each site, the NAVD88 elevations were recalculated to local mean sea level as measured by water level loggers. The nonparametric Wilcoxon rank sum statistic (Mann-Whitney $U$ ) was used to test the elevation differences between marshes and ponds for each field site $(\alpha=0.05)$.

Additional topographic measurements were performed at the transitions from vegetated marshes to unvegetated pond areas. At these transitions, we measured two points on the vegetated marsh platform, one as close as possible to the pond edge and still in the marsh vegetation, and one point approximately $1 \mathrm{~m}$ from the pond edge. Similarly, two elevation points were recorded in the unvegetated pond areas, one as close as possible to the pond edge and one approximately $1 \mathrm{~m}$ from the pond edge in the pond. Horizontal distances between these points were calculated from the point coordinates (horizontal error $<2 \mathrm{~cm}$ ), and subsequently the slope (elevation change divided by horizontal distance) was calculated in between subsequent marsh 


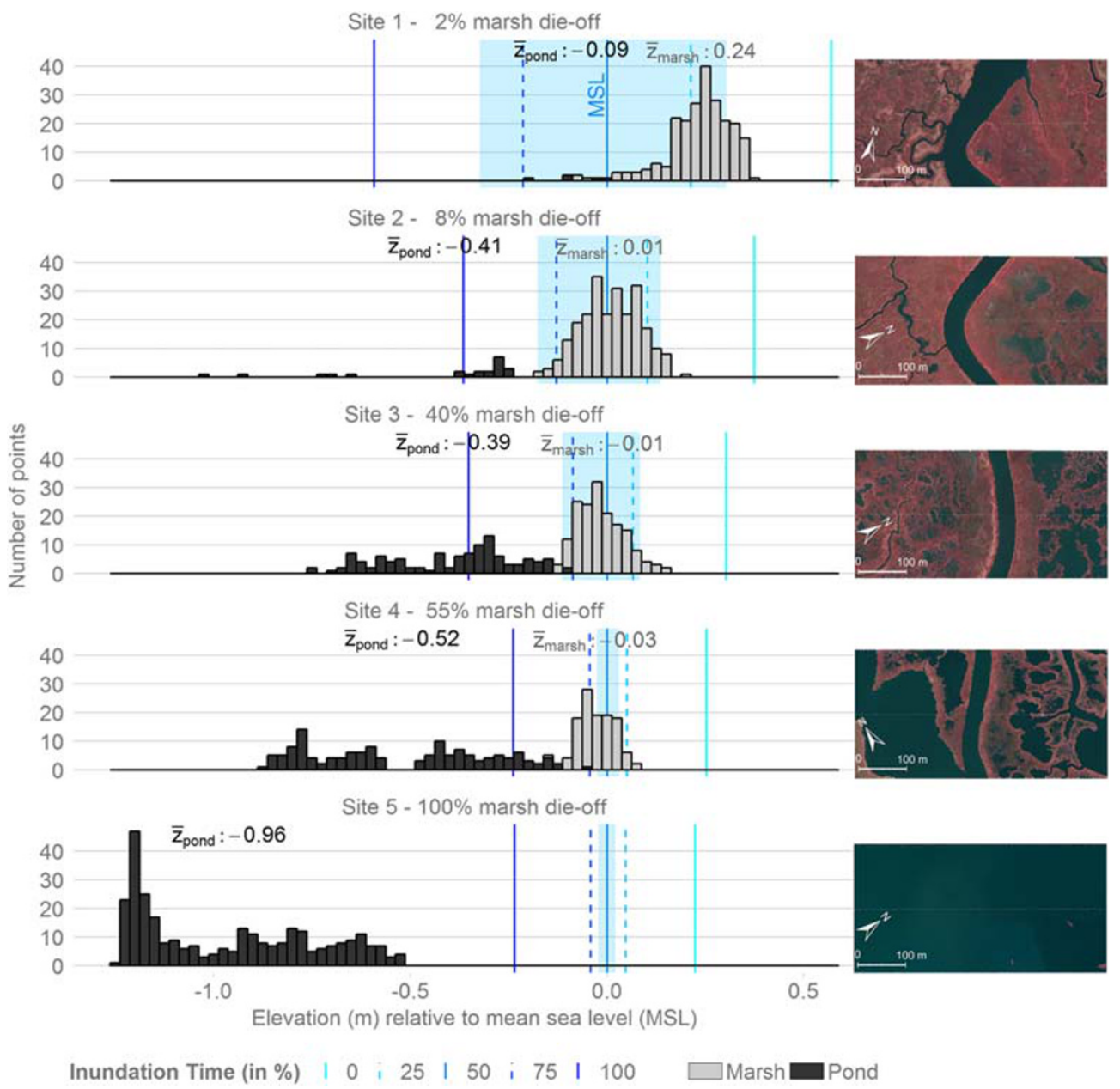

Figure 1. Elevation distribution of marsh (gray) and pond (black) points (marsh areas that converted to bare patches or open water without vegetation) for the five field sites (1-5) with increasing vegetation loss in upstream direction along the Blackwater River. Histogram bin width is $0.025 \mathrm{~m}$. Inundation time (in \%) quartiles are visualized as blue vertical lines; the average semidiurnal tidal range is visualized as a light blue rectangle. Aerial images of the sites are visualized on the right, with reddish colors representative for marsh vegetation and darker areas for open water.

points, pond points, and for the transition from marshes to ponds. The slope differences between these three morphological units were tested with the nonparametric pairwise Wilcoxon rank sum test with Bonferroni correction $(\alpha=0.05)$.

\subsection{Water Level Measurements}

Water levels were measured every $15 \mathrm{~min}$ at each field site from 14 August to 29 October 2014. Pressure transducers (Hobo U20L-02, Onset, MA, USA) were deployed in a PVC (polyvinylchloride) stilling tube at the river bank, and the elevation of each sensor was recorded with a high-precision GPS (see previous paragraph) to refer the water level data to the NAVD88 vertical datum after local atmospheric pressure compensation. Tidal characteristics (including mean high water level, mean low water level, mean semidiurnal tidal range, and relation between elevation and inundation time [in \%]) for each field site were calculated with the Tides package in R (Cox \& Schepers, 2017).

\subsection{Environmental Variables as Potential Controls on Soil Elevation}

We studied the influence of several environmental variables on marsh surface elevation and pond bottom elevation derived from an aerial image of 2010 classified into vegetated marsh areas, ponds, and the Blackwater River (Schepers et al., 2017). To examine how marsh and pond elevations varied along the marsh loss gradient, we calculated the river length from the middle of each field site to the mouth of the Blackwater 
River. This variable accounts for several potential large-scale environmental differences between the field sites such as differences in tidal range and sediment availability, which both are known to decrease with increasing upstream distance along the Blackwater river (Ganju et al., 2013; for tidal range see previous section).

To test if marsh surface elevation is related to distance from open water, we calculated the Euclidean distance of each marsh point to the Blackwater River, to secondary channels that are directly connected with the Blackwater River, and to inner marsh ponds.

To test if pond bottom elevation is related to the degree of connectivity between the pond and the Blackwater River, we measured the minimum width of the channel connecting each pond with the Blackwater River and the distance to the Blackwater River. The minimum width for each connecting channel was calculated as the double of the minimum distance from the centerline (the middle of the connecting channel) to the channel banks. Ponds that were not connected received a value of 0 . The connection distance was defined as the minimum travel distance from each pond point to the Blackwater River along secondary channels or water bodies. To include unconnected ponds in the analysis, the connection distance was categorized in four classes: not connected, connection $<2,000 \mathrm{~m}$, connection 2,000-4,000 m, and connection $>4,000 \mathrm{~m}$. These connected classes coincide with three modes in the distance distribution.

To study the potential effect of waves on pond bottom elevation, we calculated the distance of each pond point to the nearest vegetated marsh and estimated the wind fetch length. The latter is defined here as the length of a line that covers a continuous water surface from one side of the pond to the other. This was determined in four directions and averaged for each pond point (Schepers et al., 2017).

Finally, we tested the effect of pond age on pond bottom elevation. We defined the minimum age of the pond points based on aerial images of 1938, 1981, 1995, 2006, 2010, and 2013. Our fieldwork was carried out in 2014, so the minimum age is 2014 subtracted by the year of the earliest aerial image on which the point was located in a pond.

\subsection{Statistical Analyses}

To test which environmental variables (see previous section) significantly influence the soil elevation, we fitted a linear regression model to explain the elevation of the vegetated marsh platform using 916 marsh elevation points. We started the marsh model selection with four calculated variables: (1) downstream river length to the river mouth, (2) the Euclidean distance to the Blackwater River, (3) distance to secondary channels that are directly connected with the Blackwater River, and (4) distance to inner marsh ponds. A second model was fitted with 692 pond points to explain the pond bottom elevations. The mean fetch length variable was omitted to avoid collinearity with distance to the nearest marsh. We started the pond model with five variables: (1) downstream river length to the river mouth, (2) the (log) distance to the nearest marsh, (3) minimum width and (4) length of connecting channel, and (5) the minimum pond age. Each of the two models started with all the variables, followed by a backward model selection until only significant variables were present in the model (Zuur et al., 2009); see Text S1. All statistics were performed in R, version 3.2.2 (R Core Team, 2017).

We performed random forest analyses to validate the results of both linear regression models (see supporting information).

\section{Results}

\subsection{Indications for the Existence of Alternative Elevation States}

Several indicators, including bimodality of the elevation distribution and sharp elevation transitions between one state and the other, both in space and time, point to alternative state behavior of marshes and ponds.

A bimodal distribution of a key environmental variable can be an indicator of alternative stable states, with each mode focusing around the equilibrium values that characterize each state (Scheffer \& Carpenter, 2003; Schröder et al., 2005). The elevation measurements have a bimodal distribution with different marsh and open water pond elevations (Figure 1). At Field Site 1, with almost intact marshes and very few ponds, 
the marsh has a clear unimodal elevation distribution around $0.25 \mathrm{~m}$ relative to mean sea level. At Field Sites $2-5$, which represent a gradient of increasing marsh loss and hence an increasing proportion of pond data (Table S1) and pond area (Schepers et al., 2017), the pond elevations are decreasing compared to the marshes. This results in a bimodal elevation distribution, characterized by the separation of the elevation distributions of higher elevation, vegetated marshes from low elevation, unvegetated ponds, and a low occurrence of intermediate elevations (Figure 1). At all field sites, including the most intact, the ponds and marshes occupied a significantly different elevation $(p<0.001)$. However, it seems that an equilibrium elevation in the ponds has only been reached at Field Site 5, Lake Blackwater, which has a mode at $1.2 \mathrm{~m}$ below mean sea level.

Another potential indicator of alternative stable states is a sharp spatial boundary between contrasting sites (Scheffer \& Carpenter, 2003; Schröder et al., 2005). The transitions from the marsh platform to the pond bottom are steep (Figure 2), with slopes typically exceeding 0.5 . In contrast, slopes within the marshes and ponds are more gradual (typically $~ 0.01$ ) and not statistically different from each other (Figure 2). Steep transitions or cliffs are also observed at marsh-tidal flat borders in other areas and interpreted there as indicative of bistable states (van de Koppel et al., 2005). In our study area, the pond cliffs probably emerge from the different feedback mechanisms between marshes and ponds: It is known that marshes maintain high elevations in the tidal frame by capturing sediment or building up organic matter (Baustian et al., 2012; Mudd et al., 2010; Temmerman et al., 2012). But ponds lacking the vegetation-induced sedimentation feedback are unable to capture sediment and deepen by the collapse of the soil and root structure (Day et al., 2011; Delaune \& Pezeshki, 1994; van Huissteden \& van de Plassche, 1998), thus increasing the elevation deficit between marshes and ponds.

Our analyses did not identify the minimum age of ponds as a significant explanatory variable explaining pond depth (Figure 3, right, Table S3, and Figure S4). This suggests that pond deepening is not a gradual process that continues at a steady rate. Maximum pond depths for the different pond age classes increased from pond ages of 4 to 33 years and remained similar for pond ages between 33 and 76 years (Figure 3, right). This suggests that pond depths can reach a maximum (close to $-1.5 \mathrm{~m}$ ) in a relatively short time ( $\sim 33$ years) after which deepening with time is minimal. It corroborates with our above discussed indicators of alternative stable states, as state shifts would occur relatively rapidly until a new stable state is reached (Scheffer \& Carpenter, 2003; Schröder et al., 2005; Wang \& Temmerman, 2013).

Bimodality of the elevation distribution, steep cliffs, and the relatively quick deepening of marsh elevation to interior ponds suggest alternative state behavior. In addition, our analyses demonstrate that the elevation of marshes and interior ponds is sustained by different factors and feedback mechanisms. Marshes maintain high elevations in the tidal frame by capturing sediment from the water column. This is evident as marsh elevations decrease upstream and with increasing distance from the Blackwater River, reflecting gradients in tidal range and sediment availability (Text S1 and Tables S1 and S2) (Christiansen et al., 2000; Friedrichs \& Perry, 2001; Ganju et al., 2015; Moskalski \& Sommerfield, 2012; Temmerman et al., 2003). However, pond elevations are linked to erosion and sediment export (see next paragraphs). Consequently, this suggests that marshes and interior ponds represent different stable elevation states.

\subsection{Ponds Deepen With Increasing Pond Size and Wider Connections to the Tidal Channel System}

Little is known about the factors influencing pond depth. Here we demonstrate that pond depth increases with pond size and wider connections to the tidal channel system and that these factors are linked to erosion and sediment export.

As a general pattern, pond elevation measurements demonstrate that the elevation decreases with increasing marsh loss and hence increasing total pond surface area. The average pond elevation decreases from -0.41 to $-0.52 \mathrm{~m}$ between Field Sites 2 to 4 and further to $-0.96 \mathrm{~m}$ at Field Site 5 (Figure 1), where marshes have completely converted to open water (Figure S2). Our statistical model indicates that the distance of points to the nearest marsh edge and the minimum width of channels connecting the ponds to the tidal channel network are the two statistically significant variables explaining the variations in pond bottom elevation (Figure 3 and Table S3). Other factors, including downstream distance to river mouth, length of 


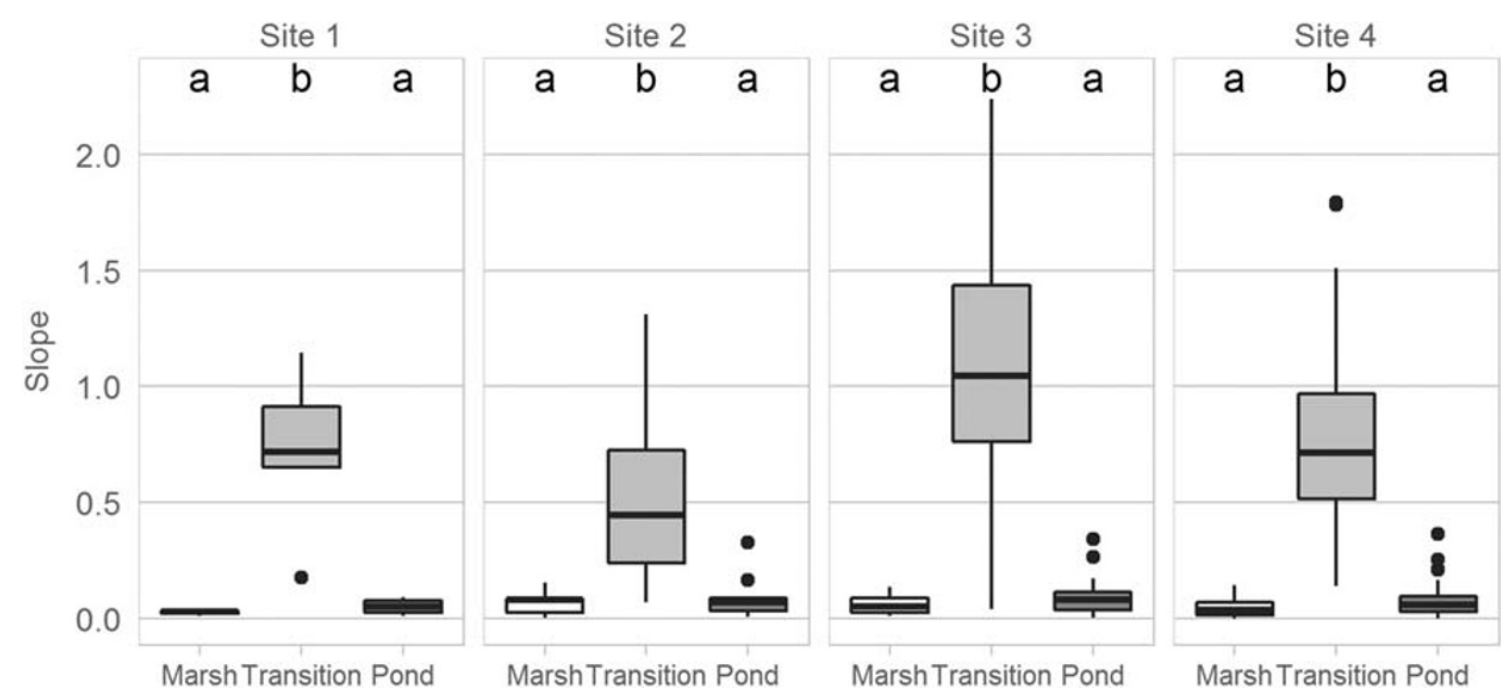

Figure 2. The elevation differences in marshes or ponds are significantly more gentle than at the transition between the two states, as shown in boxplots of the slopes within marshes, the transition from marshes to ponds, and within ponds for Sites 1-4. Within each site, significantly different slopes are labeled with different letters (pairwise Wilcoxon rank sum test with Bonferroni correction, $\alpha=0.05$ ). At the transitions of Site 3 , two points with slope 2.8 and 6.8 are not visible on the figure.
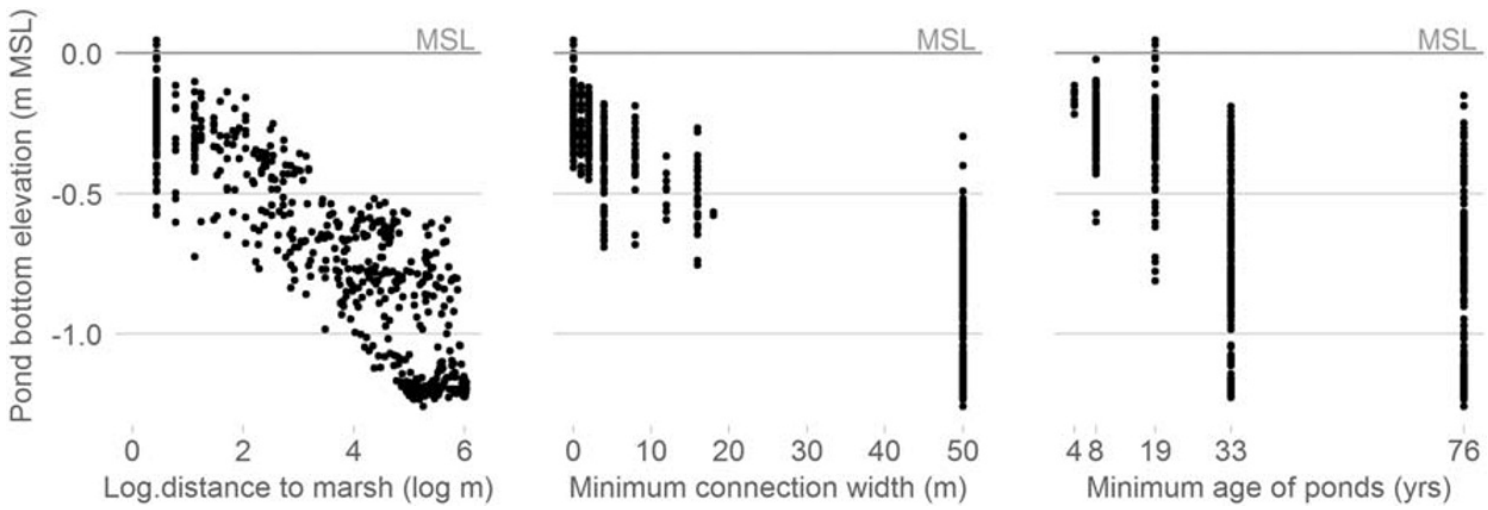

Figure 3. Pond bottom elevation (in $\mathrm{m}$ relative to mean sea level) with distance (logarithmically transformed) to the nearest marsh (left), the minimum width of the channel connecting ponds to the tidal channel network (middle), and minimum pond age (right figure). Multiple linear regression analysis (supporting information and Table S3) revealed that the distance to the marsh and the minimum width are significantly related to pond depth; minimum age was not significant. 
(a) shallow, isolated pond; elevation loss mainly by soil organic

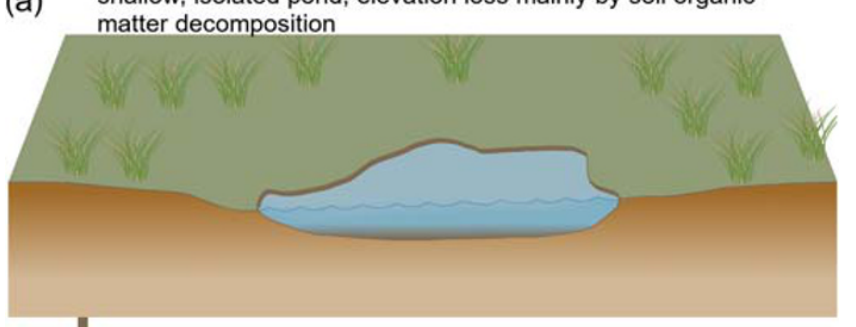

(b) pond gets connected to channel;

weak pond bottom material is eroded by waves and tides, and exported through connecting channel which deepens the pond

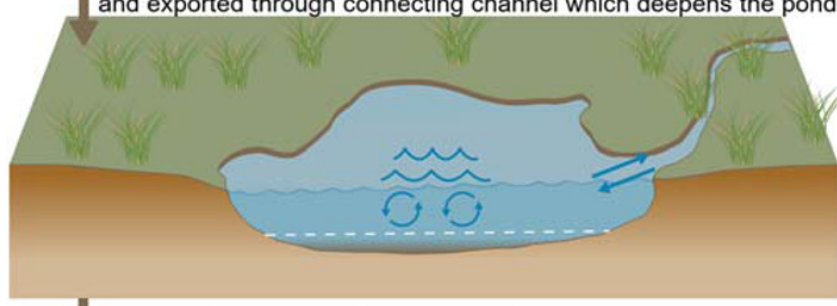

(c) deeper \& larger ponds have large tidal prism and wider connecting channels, which further facilitates tidal sediment export \& pond deepening

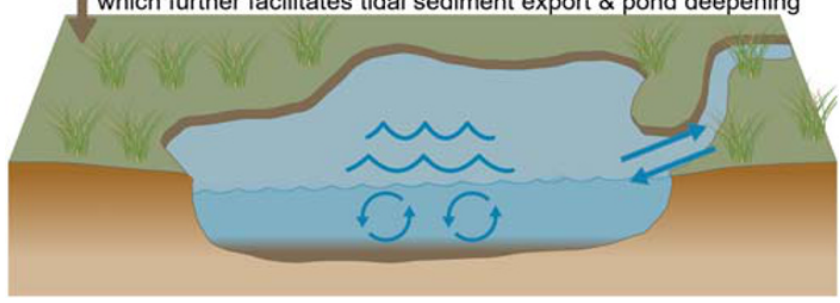

Figure 4. Conceptual model of subsequent stages and mechanisms of pond bottom deepening. occurs in ponds that are smaller than the critical pond size for pond edge erosion (Schepers, 2017; Stevenson et al., 1985).

We identify the connection of ponds to the tidal channel system as a new important mechanism for exporting sediments from ponds, as we find that ponds get deeper with wider connecting channels (Figure 3, middle; and conceptual model in Figure 4). The width of connecting channels is controlled by pond size (Pearson's $r$ : 0.89) as larger ponds have a larger tidal prism (i.e., larger tidal volumes flooding and draining from the ponds) and marsh channels that convey a larger tidal prism are known to develop larger channel widths (D'Alpaos et al., 2010; Rinaldo et al., 1999; Vandenbruwaene et al., 2013). Previous measurements in our study area indicate that tidal currents cause net sediment export via the channel system and that this is maximized during northwesterly wind events, which corresponds with the orientation of ponds, suggesting that pond erosion is the dominant contributor to the sediment export (Ganju et al., 2013; Stevenson et al., 1985). Across eight microtidal sites along the U.S. Atlantic and Pacific coasts, including our study area, a larger pond-to-marsh surface ratio correlates with larger sediment export through the channels (Ganju et al., 2017). These all indicate that ponds are major source areas of sediments that are exported by tidal currents via the channel system. Although we have no direct observations of tidal currents and sediment transport in the ponds themselves, pond bottoms typically consist of very loose, liquefied soil material that is easily suspended and exported by tidal currents via the channels connected to ponds (Stevenson et al., 1985). The wider the connecting channel, the lower the pond bottom elevation (Figure 3, middle), suggesting that export is facilitated when connecting channels are wider. Wider channels are generally also deeper (e.g., D'Alpaos et al., 2010; Vandenbruwaene et al., 2013), which would imply lower bottom friction and would enable stronger tidal currents and larger sediment export. Resuspension and export of loose pond bottom material close to the pond edge would steepen the pond-marsh transition and make the pond edge more susceptible for slumping (e.g., Mariotti et al., 2016; Stevenson et al., 1985). As such export of pond sediments may contribute to further pond expansion as well as deepening (see conceptual model in Figure 4).

The mechanism of pond deepening and expansion driven by tidal connections adds to previous work that focused on wind-driven erosion as the primary mechanism of pond expansion (Mariotti \& Fagherazzi, 2013; Ortiz et al., 2017). Previous studies show that a connection with the tidal channel system drains ponds and thereby enables plant reestablishment, followed by fast sediment accretion (Millette et al., 2010; Perillo et al., 1996; Redfield, 1972; C. A. Wilson et al., 2014; K. R. Wilson et al., 2009, 2010). Channel-driven pond expansion and permanent marsh loss in our Field Sites 2-5 (Schepers et al., 2017; Stevenson et al., 1985) seem contradictory to these studies. We suggest the low tidal range of our site as a potential explanation for the different behavior, where a relatively small loss in elevation results in a large increase of tidal inundation time and hence increased stress for plant reestablishment (Kearney \& Turner, 2016; Kirwan \& Guntenspergen, 2010).

While our study highlights feedback mechanisms between pond bottom erosion, pond size, and pond connection to the channel network, little is known on how initially small and unconnected ponds deepen and expand, that is, before the identified feedback mechanisms start to play a role. It has been suggested that biochemical decomposition of the organic material at the bottom and edges of the ponds is the main driver of initial pond deepening and expansion (DeLaune et al., 1994; van Huissteden \& van de Plassche, 1998). The fact that pond age is not a significant factor determining pond depth, also when only small ( $<100 \mathrm{~m})$ unconnected ponds are included in the regression model analysis (results not shown), suggests that the early stages of pond deepening do not occur gradually with time. Hence, identifying the drivers of initial pond deepening and expansion is an unresolved issue that merits further research. 


\section{Data Availability Statement}

The data used in this manuscript are available online in the Marine Data Archive:

1. Schepers, L.; Brennand, P.; Kirwan, M.L.; Guntenspergen, G.R.; Temmerman, S.; (2020): Elevation measurements along a historical marsh loss gradient in the Blackwater Estuary, MD, USA in 2014. Marine Data Archive. https://doi.org/10.14284/405

2. Schepers, L.; Brennand, P.; Kirwan, M.L.; Guntenspergen, G.R.; Temmerman, S.; (2020): Water level measurements along a historical marsh loss gradient in the Blackwater Estuary, MD, USA in 2014. Marine Data Archive. https://doi.org/10.14284/407

3. Schepers, L.; Brennand, P.; Kirwan, M.L.; Guntenspergen, G.R.; Temmerman, S.; (2020): Elevation measurements of marsh-pond transitions along a historical marsh loss gradient in the Blackwater Estuary, MD, USA in 2014. Marine Data Archive. https://doi.org/10.14284/413

\section{Acknowledgments}

This project was financed by an UA-BOF DOCPRO grant (to L. S. and S. T.), the Research Foundation Flanders (FWO, PhD grant to L. S. [11S9614N]; travel grants to L. S. [V428214N] and S. T. [K217414N]). G. G. and P. B. acknowledge support from the U.S. Geological Survey Land Change Science Climate R\&D Program and U.S. Geological Survey Ecosystems Mission Area. M. K. acknowledges support by NSF GLD 1529245, NSF SEES 1426981, and NSF LTER 1237733 We would like to thank the managers and biologists of the Blackwater National Wildlife Refuge for their assistance and valuable comments. We thank Erik Fransen and Joanna Horemans (University of Antwerp) for their feedback and help with the statistical analysis. Any use of trade, product, or firm names is for descriptive purposes only and does not imply endorsement by the U.S. Government. The Spartina plants in Figure 4 are by Tracey Saxby, Integration and Application Network, University of Maryland Center for Environmental Science (ian.umces.edu/imagelibrary/).

\section{References}

Barbier, E. B., Hacker, S. D., Kennedy, C., Koch, E. W., Stier, A. C., \& Silliman, B. R. (2011). The value of estuarine and coastal ecosystem services. Ecological Monographs, 81(2), 169-193. https://doi.org/10.1890/10-1510.1

Baustian, J. J., Mendelssohn, I. A., \& Hester, M. W. (2012). Vegetation's importance in regulating surface elevation in a coastal salt marsh facing elevated rates of sea level rise. Global Change Biology, 18(11), 3377-3382. https://doi.org/10.1111/j.1365-2486.2012.02792.x

Carniello, L., Defina, A., \& D'Alpaos, L. (2009). Morphological evolution of the Venice lagoon: Evidence from the past and trend for the future. Journal of Geophysical Research, 114, F04002. https://doi.org/10.1029/2008JF001157

Christiansen, T., Wiberg, P. L., \& Milligan, T. G. (2000). Flow and sediment transport on a tidal salt marsh surface. Estuarine, Coastal and Shelf Science, 50(3), 315-331. https://doi.org/10.1006/ecss.2000.0548

Cox, T., \& Schepers, L. (2017). Tides: Quasi-periodic time series characteristics. R package version 2.0. https://cran.r-project.org/web/ packages/Tides. Retrieved from http://cran.r-project.org/package=Tides

D'Alpaos, A., Lanzoni, S., Marani, M., \& Rinaldo, A. (2010). On the tidal prism-channel area relations. Journal of Geophysical Research, 115 , F01003. https://doi.org/10.1029/2008JF001243

Day, J. W., Kemp, G. P., Reed, D. J., Cahoon, D. R., Boumans, R. M., Suhayda, J. M., \& Gambrell, R. (2011). Vegetation death and rapid loss of surface elevation in two contrasting Mississippi delta salt marshes: The role of sedimentation, autocompaction and sea-level rise. Ecological Engineering, 37(2), 229-240. https://doi.org/10.1016/j.ecoleng.2010.11.021

DeLaune, R. D., Nyman, J. A., \& Patrick, W. H. (1994). Peat collapse, ponding and wetland loss in a rapidly submerging coastal marsh. Journal of Coastal Research, 10(4), 1021-1030. Retrieved from. https://doi.org/10.2307/4298293

Delaune, R. D. D., \& Pezeshki, S. R. R. (1994). The influence of subsidence and saltwater intrusion on coastal marsh stability: Louisiana Gulf Coast, U.S.A. Journal of Coastal Research, Sp, 1, 77-89.

Duarte, C. M., Losada, I. J., Hendriks, I. E., Mazarrasa, I., \& Marbà, N. (2013). The role of coastal plant communities for climate change mitigation and adaptation. Nature Climate Change, 3, 961-968. https://doi.org/10.1038/nclimate1970

Fagherazzi, S., Carniello, L., D'Alpaos, L., \& Defina, A. (2006). Critical bifurcation of shallow microtidal landforms in tidal flats and salt marshes. Proceedings of the National Academy of Sciences of the United States of America, 103(22), 8337-8341. https://doi.org/10.1073/ pnas.0508379103

Friedrichs, C. T., \& Perry, J. E. (2001). Tidal salt marsh morphodynamics: A synthesis. Journal of Coastal Research, SI, $27,7-37$.

Ganju, N. K., Defne, Z., Kirwan, M. L., Fagherazzi, S., D'Alpaos, A., \& Carniello, L. (2017). Spatially integrative metrics reveal hidden vulnerability of microtidal salt marshes. Nature Communications, 8, 14156. https://doi.org/10.1038/ncomms14156

Ganju, N. K., Kirwan, M. L., Dickhudt, P. J., Guntenspergen, G. R., Cahoon, D. R., \& Kroeger, K. D. (2015). Sediment transport-based metrics of wetland stability. Geophysical Research Letters, 42, 7992-8000. https://doi.org/10.1002/2015GL065980

Ganju, N. K., Nidzieko, N. J., \& Kirwan, M. L. (2013). Inferring tidal wetland stability from channel sediment fluxes: Observations and a conceptual model. Journal of Geophysical Research: Earth Surface, 118, 2045-2058. https://doi.org/10.1002/jgrf.20143

Kearney, M. S., Grace, R. E., \& Stevenson, J. C. (1988). Marsh loss in Nanticoke estuary, Chesapeake Bay. Geographical Review, 78(2), 205-220. https://doi.org/10.2307/214178

Kearney, M. S., \& Turner, R. E. (2016). Microtidal marshes: Can these widespread and fragile marshes survive increasing climate-sea level variability and human action? Journal of Coastal Research, 319, 686-699. https://doi.org/10.2112/JCOASTRES-D-15-00069.1

Kendrot, S. R. (2011). Restoration through eradication: Protecting Chesapeake Bay marshlands from invasive nutria (Myocastor coypus). In C. R. Veitch, M. N. Clout, \& D. R. Towns (Eds.), Island invasives: Eradication and management. Proceedings of the International Conference on Island Invasives (pp. 313-319). Gland, Switzerland: IUCN and Auckland, New Zealand: CBB.

Kirwan, M. L., \& Guntenspergen, G. R. (2010). Influence of tidal range on the stability of coastal marshland. Journal of Geophysical Research, 115, F02009. https://doi.org/10.1029/2009JF001400

Kirwan, M. L., \& Megonigal, J. P. (2013). Tidal wetland stability in the face of human impacts and sea-level rise. Nature, 504, 53-60. https:// doi.org/10.1038/nature12856

Marani, M., D'Alpaos, A., Lanzoni, S., Carniello, L., \& Rinaldo, A. (2010). The importance of being coupled: Stable states and catastrophic shifts in tidal biomorphodynamics. Journal of Geophysical Research, 115, F04004. https://doi.org/10.1029/2009JF001600

Mariotti, G. (2016). Revisiting salt marsh resilience to sea level rise: Are ponds responsible for permanent land loss? Journal of Geophysical Research: Earth Surface, 121, 1391-1407. https://doi.org/10.1002/2016JF003900

Mariotti, G., \& Fagherazzi, S. (2013). Critical width of tidal flats triggers marsh collapse in the absence of sea-level rise. Proceedings of the National Academy of Sciences of the United States of America, 110(14), 5353-5356. https://doi.org/10.1073/pnas.1219600110

Mariotti, G., Kearney, W. S., \& Fagherazzi, S. (2016). Soil creep in salt marshes. Geology, 44, 459-462. https://doi.org/10.1130/G37708.1

McLeod, E., Chmura, G. L., Bouillon, S., Salm, R., Björk, M., Duarte, C. M., et al. (2011). A blueprint for blue carbon: Toward an improved understanding of the role of vegetated coastal habitats in sequestering $\mathrm{CO}_{2}$. Frontiers in Ecology and the Environment, 9(10), 552-560. https://doi.org/10.1890/110004 
Millette, T. L., Argow, B. A., Marcano, E., Hayward, C., Hopkinson, C. S., \& Valentine, V. (2010). Integration of multitemporal multispectral remote sensing with LIDAR and GIS. Journal of Coastal Research, 265(265), 809-816. https://doi.org/10.2112/JCOASTRES-D-09-00101.1

Moffett, K. B., \& Gorelick, S. M. (2016). Alternative stable states of tidal marsh vegetation patterns and channel complexity. Ecohydrology, 9 , 1639-1662. https://doi.org/10.1002/eco.1755

Möller, I., Kudella, M., Rupprecht, F., Spencer, T., Paul, M., van Wesenbeeck, B. K., et al. (2014). Wave attenuation over coastal salt marshes under storm surge conditions. Nature Geoscience, 7, 727-731. https://doi.org/10.1038/ngeo2251

Morris, J. T., Sundareshwar, P. V., Nietch, C. T., Kjerfve, B., \& Cahoon, D. R. (2002). Responses of coastal wetlands to rising sea level. Ecology, 83(10), 2869-2877. https://doi.org/10.1890/0012-9658(2002)083[2869:ROCWTR]2.0.CO;2

Morton, R. A., Tiling, G., \& Ferina, N. F. (2003). Causes of hot-spot wetland loss in the Mississippi delta plain. Environmental Geosciences, 10(2), 71-80. https://doi.org/10.1306/eg100202007

Moskalski, S. M., \& Sommerfield, C. K. (2012). Suspended sediment deposition and trapping efficiency in a Delaware salt marsh. Geomorphology, 139-140, 195-204. https://doi.org/10.1016/j.geomorph.2011.10.018

Mudd, S. M., D'Alpaos, A., \& Morris, J. T. (2010). How does vegetation affect sedimentation on tidal marshes? Investigating particle capture and hydrodynamic controls on biologically mediated sedimentation. Journal of Geophysical Research, 115, F03029. https://doi.org/ $10.1029 / 2009$ JF001566

Ortiz, A. C., Roy, S., \& Edmonds, D. A. (2017). Land loss by pond expansion on the Mississippi River Delta plain. Geophysical Research Letters, 44, 3635-3642. https://doi.org/10.1002/2017GL073079

Penland, S., Wayne, L., Britsch, D., Williams, S. J., Beall, A. D., \& Butterworth, V. (2000). Geomorphic classification of coastal land loss between 1932 and 1990 in the Mississippi River Delta plain, Southeastern Louisiana. USGS Open File Report 00-417. https://pubs.usgs.gov/ of/2000/of00-417/

Perillo, G. M. E., Ripley, M. D., Piccolo, M. C., \& Dyer, K. R. (1996). The formation of tidal creeks in a salt marsh: New evidence from the Loyola Bay salt marsh, Rio Gallegos estuary, Argentina. Mangroves and Salt Marshes, 1(1), 37-46. https://doi.org/10.1023/ A:1025942111382

R Core Team. (2017). R: A language and environment for statistical computing. The R Foundation for Statistical Computing, Vienna, Austria. https://www.r-project.org/

Redfield, A. C. (1972). Development of a New England salt marsh. Ecological Monographs, 42(2), 201-237. https://doi.org/10.2307/1942263

Rinaldo, A., Fagherazzi, S., Lanzoni, S., Marani, M., \& Dietrich, W. E. (1999). Tidal networks: 3. Landscape-forming discharges and studies in empirical geomorphic relationships. Water Resources Research, 35(12), 3919-3929. https://doi.org/10.1029/1999WR900238

Sallenger, A. H., Doran, K. S., \& Howd, P. A. (2012). Hotspot of accelerated sea-level rise on the Atlantic coast of North America. Nature Climate Change, 2(12), 884-888. https://doi.org/10.1038/nclimate1597

Scheffer, M., Carpenter, S., Foley, J. A., Folke, C., \& Walker, B. (2001). Catastrophic shifts in ecosystems. Nature, 413(6856), 591-596. https://doi.org/10.1038/35098000

Scheffer, M., \& Carpenter, S. R. (2003). Catastrophic regime shifts in ecosystems: Linking theory to observation. Trends in Ecology \& Evolution, 18(12), 648-656. https://doi.org/10.1016/j.tree.2003.09.002

Schepers, L. (2017). Spatial patterns and bio-geomorphological effects of vegetation loss in a submerging coastal marsh (Doctoral dissertation). Antwerp, Belgium: University of Antwerp. Retrieved from University of Antwerp Institutional Repository (https://hdl.handle.net/ 10067/1479440151162165141).

Schepers, L., Kirwan, M., Guntenspergen, G., \& Temmerman, S. (2017). Spatio-temporal development of vegetation die-off in a submerging coastal marsh. Limnology and Oceanography, 62, 137-150. https://doi.org/10.1002/lno.10381

Schepers, L., Kirwan, M. L., Guntenspergen, G. R., \& Temmerman, S. (2020). Evaluating indicators of marsh vulnerability to sea level rise along a historical marsh loss gradient. Earth Surface Processes and Landforms, 45(9), 2107-2117. https://doi.org/10.1002/esp.4869

Schröder, A., Persson, L., \& De Roos, A. M. (2005). Direct experimental evidence for alternative stable states: A review. Oikos, 110(1), 3-19. https://doi.org/10.1111/j.0030-1299.2005.13962.x

Stark, J., Van Oyen, T., Meire, P., \& Temmerman, S. (2015). Observations of tidal and storm surge attenuation in a large tidal marsh. Limnology and Oceanography, 60, 1371-1381. https://doi.org/10.1002/lno.10104

Stevenson, J. C., Kearney, M. S., \& Pendleton, E. C. (1985). Sedimentation and erosion in a Chesapeake Bay brackish marsh system. Marine Geology, 67(1588), 213-235. https://doi.org/10.1016/0025-3227(85)90093-3

Temmerman, S., Govers, G., Wartel, S., \& Meire, P. (2003). Spatial and temporal factors controlling short-term sedimentation in a salt and freshwater tidal marsh, Scheldt estuary, Belgium, SW Netherlands. Earth Surface Processes and Landforms, 28, 739-755. https://doi.org/ 10.1002/esp.495

Temmerman, S., Govers, G., Wartel, S., \& Meire, P. (2004). Modelling estuarine variations in tidal marsh sedimentation: Response to changing sea level and suspended sediment concentrations. Marine Geology, 212, 1-19. https://doi.org/10.1016/j.margeo.2004.10.021

Temmerman, S., Meire, P., Bouma, T. J., Herman, P. M. J., Ysebaert, T., \& De Vriend, H. J. (2013). Ecosystem-based coastal defence in the face of global change. Nature, 504, 79-83. https://doi.org/10.1038/nature12859

Temmerman, S., Moonen, P., Schoelynck, J., Govers, G., \& Bouma, T. J. (2012). Impact of vegetation die-off on spatial flow patterns over a tidal marsh. Geophysical Research Letters, 39, L03406. https://doi.org/10.1029/2011GL050502

van Belzen, J., van de Koppel, J., Kirwan, M. L., van der Wal, D., Herman, P. M. J., Dakos, V., et al. (2017). Vegetation recovery in tidal marshes reveals critical slowing down under increased inundation. Nature Communications, 8(1), 1-7. https://doi.org/10.1038/ ncomms15811

van de Koppel, J., van der Wal, D., Bakker, J. P., \& Herman, P. M. J. (2005). Self-organization and vegetation collapse in salt marsh ecosystems. The American Naturalist, 165(1), E1-E12. https://doi.org/10.1086/426602

van Huissteden, J., \& van de Plassche, O. (1998). Sulphate reduction as a geomorphological agent in tidal marshes ('great marshes' at Barnstable, Cape Cod, USA). Earth Surface Processes and Landforms, 23(3), 223-236. https://doi.org/10.1002/(SICI)10969837(199803)23:3<223::AID-ESP843>3.0.CO;2-I

Vandenbruwaene, W., Bouma, T. J., Meire, P., \& Temmerman, S. (2013). Bio-geomorphic effects on tidal channel evolution: Impact of vegetation establishment and tidal prism change. Earth Surface Processes and Landforms, 38, 122-132. https://doi.org/10.1002/esp.3265

Wang, C., \& Temmerman, S. (2013). Does biogeomorphic feedback lead to abrupt shifts between alternative landscape states?: An empirical study on intertidal flats and marshes. Journal of Geophysical Research: Earth Surface, 118, 229-240. https://doi.org/10.1029/ 2012JF002474

Wilson, C. A., Hughes, Z. J., FitzGerald, D. M., Hopkinson, C. S., Valentine, V., \& Kolker, A. S. (2014). Saltmarsh pool and tidal creek morphodynamics: Dynamic equilibrium of northern latitude saltmarshes? Geomorphology, 213, 99-115. https://doi.org/10.1016/j. geomorph.2014.01.002 
Wilson, K. R., Kelley, J. T., Croitoru, A., Dionne, M., Belknap, D. F., \& Steneck, R. (2009). Stratigraphic and ecophysical characterizations of salt pools: Dynamic landforms of the Webhannet salt marsh, Wells, ME, USA. Estuaries and Coasts, 32(5), 855-870. https://doi.org/ 10.1007/s12237-009-9203-7

Wilson, K. R., Kelley, J. T., Tanner, B. R., \& Belknap, D. F. (2010). Probing the origins and stratigraphic signature of salt pools from north-temperate marshes in Maine, U.S.A. Journal of Coastal Research, 26(6), 1007-1026. https://doi.org/10.2112/JCOASTRES-D-1000007.1

Zuur, A. F., Ieno, E. N., Walker, N., Saveliev, A. A., \& Smith, G. M. (2009). Mixed effects models and extensions in ecology with R. New York, NY: Springer New York. https://doi.org/10.1007/978-0-387-87458-6 